\title{
New Bacterial Concrete to Repair Cracks Through Self Healing Technique
}

\author{
Rosy $^{1}$, Chandan Kumar ${ }^{2}$, Priti Kumari ${ }^{3}$, Dr. Krishna Murari ${ }^{4}$ \\ ${ }^{1}$ UG Student, Dept. of Civil Engineering, NSIT, Bihta, Patna (India) \\ ${ }^{2}$ Assistant Professor, Dept. of Civil Engineering, NSIT, Bihta, Patna (India) \\ ${ }^{3}$ PG Scholar, Nanoscience and Nanotechnology Department, AKU, Patna (India) \\ ${ }^{4}$ Professor, Civil Engineering Department, BIT Sindri, Dhanbad (India)
}

\begin{abstract}
Cracks in concrete are unpreventable and it is intrinsic weakness of concrete. Through these cracks water and salts can seep. It initiates corrosion further reducing the life of concrete. So there was a requirement to develop an intrinsic biomaterial, a self repairing technique which can repair the cracks and fissures developed in concrete. This technique is highly desirable because the activity of crack remediation is eco friendly and natural. The paper discusses the plugging of artificial cracks in in cement concrete using Bacillus megaterium. The effect on compressive strength, water absorption and water permeability of cement concrete cubes due to mixing of bacteria is also discussed in this paper. It was found that the use of Escherichia coli improves the compressive strength and stiffness of concrete. The effect on compressive strength, water absorption and water permeability of cement concrete cubes due to mixing of bacteria is also discussed in this paper. It was found that the use of Escherichia coli improves the compressive strength and stiffness of concrete. It also shows that there is reduction in water absorption and water permeability when compared to conventional concrete. The bacteria which are going to be introduced in concrete should have the properties of alkali resistance and it also should form endospore, so that it can withstand the stresses produced in concrete while mixing, handling and transporting.
\end{abstract}

Key Words: Compressive strength, Bio concrete, Water permeability, Water absorption, Escherichia coli

\section{INTRODUCTION:}

It is generally accepted that the service life of the concrete structures is reduced by the development of micro cracks which allows the ingress of water, carbon dioxide and chlorine ions into the structures. This can cause degradation of concrete and corrosion of reinforcements resulting in the needs of regular and costly repairs and maintenance works. Cracking in conventional reinforced concrete is virtually unavoided because of thermal effects early age shrinkage mechanical loading freezing and thawing or combination of these factors. In addition to the associated costs repairs increase the carbon footprints of the structures and expose them responsible for carrying them out to unnecessary levels of risks. This project aimed to develop a self healing concrete to reduce the repair and maintenance requirements of concrete structures.

\section{MATERIALS AND METHODS :}

\section{Materials}

1. Portland Pozzolona cement(30 grade)

2. Graded fine aggregates
3. Graded coarse aggregates

4. Water

5. Bacteria=Escherichia coli

Methods

1. Mix design of M25

2. Testing of materials

3. Working test

4. Identification of bacteria

5. Preparation of bacteria

6. Mixing and compacting

7. Curing

8. Implementation and testing

9. Results

Escherichia coli- Escherichia coli is an obligate aerobe bacterium used as a larvicide for mosquitoes control. It forms spherical end pore Bacillus spherical is a gram positive bacteria with rod shaped cells that forms chainsmedium sized, smooth colonies with an entire margin and also rod.

\section{Ability of bacterial concrete to repair cracks}

Both attention will be given on closure of cracks and on regaining mechanical properties. Cracks in concrete specimen subjected to various loading situations will be investigated before and after healing. For this impregnation techniques and scanning electron microscope will be applied. On the other hand the micro organisms such as cyano bacteria, algae, lichens, yeast, fungi and mosses etc which are omnipresent and omnipotent are responsible for metabolism action that results in microbial deposition of calcium carbonate layer. Also the process results in re establishment of cohesion between particles of mineral binding materials and protects against further decay of stone materials. To prove the positive effects of microbial $\mathrm{CaCO}_{3}$ precipitation. The increase in porosity of concrete leads to increase in capillary water uptake, increase in gas permeability along with higher carbonation rate, high chloride migration and freeze thaw damage.

Hand mixing

Hand mixing is practiced for small scale concrete work. Hand mixing should be done over an impervious concrete or brick floor of sufficiently large size to take one bag of cement. Spread out the measured quantity of coarse aggregates and fine aggregates in alternate layers. Pour the cement on top of it and mix them dry by shovel, turning mixture over and over again until uniformity of color is 
achieved. This uniform mixture is spread out in a thickness of about $20 \mathrm{~cm}$. This operation is continued till such a good time a good, homogenous and uniform concrete is achieved.

It is a particular importance to see that the water is not poured but only sprinkled. Water in a small quantity should be added towards the end of the mixing to get the just required consistency. At the stage even a small quantity of water makes difference. After that bacteria medium is sprayed over concrete mixture.

Placing

It is not enough that a concrete mix correctly designed batched mixed it is of utmost importance that the concrete must be placed in systematic manner to yield optimum results. The precautions to be taken and methods adopted while placing concrete in the moulds.

\section{Hand compaction}

Hand compaction of concrete is adopted in case of small concrete works. Sometimes this method is also applied in such situation where a large quantity of reinforcement is used which cannot be normally compacted by mechanical means. Hand compaction consists of rodding, ramming and tamping. When hand compaction is adopted the consistency of concrete is maintained at high level. Tamping is one of the usual methods adopted in compacting roof or floor slab or road pavements where the thickness of concrete is comparatively less and surface floor slab or road pavements where the thickness of concrete is comparatively less and surface to be finished smooth and level.

\section{Curing}

Concrete derives its strength by the hydration of cement particles. The hydration of cement is not a momentary action but a process continuing for a long time. Curing can also be described as keeping the concrete moist and warm enough so that hydration of cement can continue. More elaborately, it can be described as the process of maintaining a satisfactory moisture content and a favorable temperature in concrete during the period immediately following placement, so that the hydration of cement may continue until the desired properties are developed to a sufficient degree to meet the requirement of service. The casted cubes and cylinders are immersed in water for 3 days, 7 days, 14 days and 28 days.

\section{Workability of concrete}

Workability is the amount of useful internal required to produce full compaction of concrete It depends on

(i) Grading of coarse and fine aggregates

(ii) Quantity of cement paste

(iii) Consistency of cement paste

(iv) Type of aggregates

\section{Slump test}

Slump test is most commonly used method of measuring consistency of concrete which can be employed either in laboratory or at site of work .It is not a very suitable method for very wet or very dry concrete. It is used conventionally as a control test and gives an indication of the uniformity of concrete from batch to batch. The deformation shows the characteristic of concrete with respect for segregation. The thickness of metallic sheet for the mould should not be thinner than $1.6 \mathrm{~mm}$. For tampering the concrete, a steel tamping rod $16 \mathrm{~mm}$ diameter, 0.6 meter along with bullet end is used. The mould is then filled in 4 layers each approximately $1 / 4 \mathrm{rth}$ of the mould. Each layer is tampered 25 times by the tamping rod taking care to distribute the stroke evenly over the cross section. After the top layer has been rotted, the concrete is struck off level with a trowel and tamping rod. The mould is removed from the concrete immediately by rising it slowly and carefully in a vertical direction. This allows the concrete to subside. This subside is referred as slump of concrete.

\section{The value of slump $=85 \mathrm{~mm}$}

\section{EXPERIMENTAL STUDY}

The materials used like cement, coarse aggregates and fine aggregates are shown below. The properties of constituents are also presented in the table.

Table1.Specific gravity of coarse aggregates

\begin{tabular}{|l|l|l|l|l|l|}
\hline S.no. & $\begin{array}{l}\text { Wt.ofpycnometer+coarse } \\
\text { aggregates ,gms.(A) }\end{array}$ & $\begin{array}{l}\text { Wt.ofpycnometer+ } \\
\text { Water,gms,(B) }\end{array}$ & $\begin{array}{l}\text { Wt.ofpycnometer+ } \\
\text { coarse aggregates } \\
\text { +water,gms,(C) }\end{array}$ & $\begin{array}{l}\text { Wt.of dry } \\
\text { samples } \\
\text { gms,(D) }\end{array}$ & $\begin{array}{l}\text { Specific } \\
\text { Gravity, } \\
\text { D/(C-A+B) }\end{array}$ \\
\hline 1. & 4140 & 2900 & 1910 & 1830 & 2.73 \\
\hline
\end{tabular}

Table2. Specific gravity of fine aggregates

\begin{tabular}{|l|l|c|l|l|l|}
\hline S.No & $\begin{array}{l}\text { Wt.of } \\
\text { pycnometer } \\
\left(\mathrm{W}_{1}\right)\end{array}$ & Wt.of sand+bottle $\left(\mathrm{W}_{2}\right)$ & $\begin{array}{l}\text { Wt.of sand+bottle } \\
+ \text { water( }\left(\mathrm{W}_{3}\right)\end{array}$ & $\begin{array}{l}\text { Wt.ofwater } \\
+ \text { bottle }\left(\mathrm{W}_{4}\right)\end{array}$ & $\begin{array}{l}\text { Specific } \\
\text { Gravity } \\
\left(\mathrm{W}_{2}-\mathrm{W}_{1}\right) \\
/\left(\left(\mathrm{W}_{2}-\mathrm{W}_{1}\right) \ldots\left(\mathrm{W}_{3}\right.\right. \\
\left.\left.-\mathrm{W}_{4}\right)\right)\end{array}$ \\
\hline 1. & 390 & 590 & & & 2.667 \\
\hline
\end{tabular}

Table 3. Initial and Final setting time of cement

\begin{tabular}{|l|l|l|l|}
\hline S.No. & Type of cement & Initial setting time & Final setting time \\
\hline 1. & PPC & 30.5 minutes & 596 minutes \\
\hline
\end{tabular}

Table 4. Sieve analysis of coarse aggregates

\begin{tabular}{|l|l|l|l|l|l|}
\hline S.No. & Sieve size & $\begin{array}{l}\text { Weight of } \\
\text { soil retained }\end{array}$ & $\begin{array}{l}\% \text { of weight } \\
\text { retained }\end{array}$ & $\begin{array}{l}\% \text { cumulative } \\
\text { weight }\end{array}$ & $\begin{array}{l}\% \text { of weight } \\
\text { passing }\end{array}$ \\
\hline 1. & 25 & 0.130 & 0.007 & 0.007 & 99.993 \\
\hline 2. & 20 & 0.72 & 0.038 & 0.045 & 99.955 \\
\hline
\end{tabular}




\begin{tabular}{|l|l|l|l|l|l|}
\hline 3. & 16 & 0.65 & 0.345 & 0.39 & 99.61 \\
\hline 4. & 12.5 & 0.5 & 0.03 & 0.41 & 99.51 \\
\hline 5. & 10 & 0.105 & 0.051 & 0.4151 & 99.5849 \\
\hline 6. & 6.3 & 0.05 & 0.05 & 0.4651 & 99.5349 \\
\hline 7. & 4.75 & 0 & 0 & 0 & 99.5349 \\
\hline 8. & 2.36 & 0 & 0 & 0 & 99.5349 \\
\hline Pan & 0 & 0 & 0 & 0 & 0 \\
\hline
\end{tabular}

Table 5.Sieve analysis of fine aggregates

\begin{tabular}{|l|l|l|l|l|l|}
\hline S.No. & Sieve size & $\begin{array}{l}\text { Weight of } \\
\text { soil retained }\end{array}$ & $\begin{array}{l}\text { \% of weight } \\
\text { retained }\end{array}$ & $\begin{array}{l}\% \text { cumulative } \\
\text { weight } \\
\text { weight } \\
\text { passing }\end{array}$ \\
\hline 1. & 4.75 & 0.01 & 1.5 & 1.5 & 99.5 \\
\hline 2. & 2.36 & 0.02 & 4.0 & 5.5 & 94.5 \\
\hline 3. & 1.18 & 0.15 & 25 & 30.5 & 69.5 \\
\hline 4. & 0.6 & 0.25 & 40.5 & 71 & 29 \\
\hline 5. & 0.425 & 0.065 & 11.5 & 92.5 & 17.5 \\
\hline 6. & 0.3 & 0.06 & 10 & 92.5 & 7.5 \\
\hline 7. & 0.15 & 0.04 & 7.0 & 99.5 & 0.5 \\
\hline 8. & 0.007 & 0.005 & 0.3 & 0 & 0.2 \\
\hline Pan & 0 & 0 & 0 & & 0 \\
\hline
\end{tabular}

Table 6.Quantity of materials

\begin{tabular}{|l|l|l|}
\hline S.no. & Materials & Quantity \\
\hline 1. & Cement & $1.8 \mathrm{~kg}$ \\
\hline 2. & Fine aggregates & $3.05 \mathrm{~kg}$ \\
\hline 3. & Coarse aggregates & $4.75 \mathrm{~kg}$ \\
\hline 4. & Water & $750 \mathrm{ml}$ \\
\hline 5. & Bacterial solution & $5 \%, 10 \%, 15 \%$ \\
\hline
\end{tabular}

\section{RESULTS AND DISCUSSIONS}

\section{A. Compressive strength}

The concrete was tested for 7 days, 14 days and 28 days. of curing. It was loaded in compression testing machine. Cubes of size $15^{*} 15^{*} 15$ was used.

Compressive strength $=($ Ultimate load $) /($ Area of specimen $)=\mathrm{P} / \mathrm{A}$

where $\mathrm{P}=$ Ultimate load,

$\mathrm{A}=$ Area of specimen

The comparison between compressive strength of bacterial concrete and conventional concrete is tabulated as below:

Table 7. Compressive strength of conventional concrete

\begin{tabular}{|c|c|c|c|c|}
\hline S.No. & Days of curing & Max. load,Kn & $\begin{array}{l}\text { Compressive } \\
\text { stress,N/mm }{ }^{2}\end{array}$ & $\begin{array}{l}\text { Average, } \\
\mathrm{N} / \mathrm{mm}^{2}\end{array}$ \\
\hline 1. & \multirow{3}{*}{7 days } & 300 & 13.330 & \multirow{3}{*}{13.183} \\
\hline 2. & & 270 & 12.000 & \\
\hline 3. & & 320 & 14.220 & \\
\hline 1. & \multirow{3}{*}{14 days } & 440 & 19.556 & \multirow{3}{*}{21.035} \\
\hline 2. & & 500 & 22.220 & \\
\hline 3. & & 480 & 21.330 & \\
\hline 1. & \multirow{3}{*}{28 days } & 535 & 23.778 & \multirow{3}{*}{25.776} \\
\hline 2. & & 590 & 26.220 & \\
\hline 3. & & 615 & 27.330 & \\
\hline
\end{tabular}

Table9.Compressive strength of self healing concrete

\begin{tabular}{|c|c|c|c|c|c|}
\hline S.no. & Daysof curing & $\begin{array}{l}\% \text { of bacteria } \\
\text { added }\end{array}$ & Max. load,Kn & $\begin{array}{l}\text { Compressive } \\
\text { stress, N/mm }\end{array}$ & $\begin{array}{c}\text { Average, } \\
\mathrm{N} / \mathrm{mm}^{2}\end{array}$ \\
\hline 1. & \multirow{3}{*}{7 days } & $5 \%$ & 360 & 16.00 & \multirow{3}{*}{16.5167} \\
\hline 2. & & $10 \%$ & 370 & 16.44 & \\
\hline 3. & & $15 \%$ & 385 & 17.11 & \\
\hline 1. & \multirow{3}{*}{14 days } & $5 \%$ & 405 & 18.08 & \multirow{3}{*}{21.1367} \\
\hline 2. & & $10 \%$ & 500 & 22.22 & \\
\hline 3. & & $15 \%$ & 520 & 23.11 & \\
\hline 1. & \multirow{3}{*}{28 days } & $5 \%$ & 545 & 24.22 & \multirow{3}{*}{26.367} \\
\hline 2. & & $10 \%$ & 595 & 26.44 & \\
\hline 3. & & $15 \%$ & 640 & 28.44 & \\
\hline
\end{tabular}




\section{B. Tensile strength}

It is indirect way of finding tensile strength of concrete. After 7 days, 14 days and 28 days of curing the specimen were placed in CTM by placing horizontal.

Tensile strength $=2 \mathrm{P} / 3.14 * \mathrm{D} * \mathrm{~L}$

where,

$\mathrm{D}=15 \mathrm{~cm}$

$\mathrm{L}=30 \mathrm{~cm}$

The difference between the tensile strength of conventional and self healing concrete is shown below in the tables:

Table 9. Tensile strength of conventional concrete

\begin{tabular}{|c|c|c|c|c|}
\hline S.No & Days of curing & Max. load ,Kn & $\begin{array}{c}\text { Tensile stress } \\
\mathrm{N} / \mathrm{mm}^{2}\end{array}$ & $\begin{array}{l}\text { Average, } \\
\mathrm{N} / \mathrm{mm}^{2}\end{array}$ \\
\hline 1. & \multirow{3}{*}{7 days } & 155 & 2.19 & \multirow{3}{*}{1.767} \\
\hline 2. & & 120 & 1.69765 & \\
\hline 3. & & 100 & 1.4147 & \\
\hline 1. & \multirow{3}{*}{14 days } & 200 & 2.829 & \multirow{3}{*}{3.086} \\
\hline 2. & & 220 & 3.110 & \\
\hline 3. & & 235 & 3.320 & \\
\hline 1. & \multirow{3}{*}{28 days } & 250 & 3.500 & \multirow{3}{*}{3.590} \\
\hline 2. & & 275 & 3.890 & \\
\hline 3. & & 239 & 3.380 & \\
\hline
\end{tabular}

Table 10. Tensile strength of self healing concrete

\begin{tabular}{|c|c|c|c|c|c|}
\hline S.No. & $\begin{array}{l}\text { Days of } \\
\text { curing }\end{array}$ & $\begin{array}{l}\% \text { of bacteria } \\
\text { added }\end{array}$ & Max. load Kn & $\begin{array}{l}\text { Tensile } \\
\text { stress } \\
\mathrm{N} / \mathrm{mm}^{2}\end{array}$ & $\begin{array}{l}\text { Average, } \\
\mathrm{N} / \mathrm{mm}^{2}\end{array}$ \\
\hline 1. & \multirow{3}{*}{7 days } & $5 \%$ & 185 & 2.617 & \multirow{3}{*}{2.920} \\
\hline 2. & & $10 \%$ & 208 & 2.940 & \\
\hline 3. & & $15 \%$ & 227 & 3.211 & \\
\hline 1. & \multirow{3}{*}{14 days } & $5 \%$ & 230 & 3.250 & \multirow{3}{*}{3.455} \\
\hline 2. & & $10 \%$ & 245 & 3.466 & \\
\hline 3. & & $15 \%$ & 258 & 3.64995 & \\
\hline 1. & \multirow{3}{*}{28 days } & $5 \%$ & 252 & 3.565 & \multirow{3}{*}{3.850} \\
\hline 2. & & $10 \%$ & 280 & 3.960 & \\
\hline 3. & & $15 \%$ & 285 & 4.030 & \\
\hline
\end{tabular}

\section{CONCLUSIONS:}

- Introducing the bacteria e coli into the concrete, improves the properties and characteristics of concrete.

- Experimental investigations were conducted to determine compressive strength, split tensile strength of conventional and bio concrete.

- Based on the test results, it was observed that addition of bacteria gives better result. It was observed that both tensile and compressive strength of concrete increases due to addition of bacteria.

- It was also inferred that increase in both compressive and tensile strength was maximum when curing period was 7 days.

- Bacteria repair the cracks by producing calcium carbonate which blocks the cracks and repair it.

- It was proved that self healing concrete is better than conventional concrete because of it's eco friendly nature, self healing nature and convenience to use.

- Hence we can use bacterial concrete at the place of conventional concrete in structures to get more strength and durability.

\section{REFERENCES:}

[1] Chiara Brabesi, Alessandro Galizzi, Giogio Mastromei, Milla Rossi, Ellena, Tamburini and Brunella perito Pavia,Itlay Bacillus subtilis gene cluster involved in Gopala KrishnanS,Annie peter J,Rajname MP.Strength and Durability characteristics of concrete containing HVPA without processing.

[2] Mohit Goyal , P .krishna chaithanya, Behavior of bacterial concrete as self healing material, International journal of engineering technology and advanced engineering, ISSN22502459,5,100-103.

[3] Meera C.M., Dr.Subha Strength and durability Assessment of bacteria based self healing concrete.ISOR Journal of Mechanical and Civil engineering,01-07.

[4] IS 10262-1982 code for concrete mix design.

[5] Etaveni Madhavi and T. Divya Bhavana"'Strength properties of a Bacterial concrete with Fly ash and GGBS", International Journal Of Engineering Research and Technology (IRJET) 2016,03 .

[6] Use of bacteria to repair cracks in concrete by Kim Tittleboom, Magnel, Laboratory of Concrete research, Department of structural engineering (2013), Volume 6, pp-2182-2217. 